\title{
Influence of dietary energy level on the production of breeding ostriches
}

\author{
T.R. Olivier ${ }^{1,2}$, T.S. Brand ${ }^{1,2 \#}$ and Z. Brand ${ }^{3}$ \\ ${ }^{1}$ Institute for Animal Production: Elsenburg, Department of Agriculture, Western Cape, Private Bag X1, \\ Elsenburg 7607, South Africa \\ ${ }^{2}$ Department of Animal Sciences, University of Stellenbosch, Private Bag X1, Matieland 7602, South Africa \\ ${ }^{3}$ Institute for Animal Production: Oudtshoorn, Department of Agriculture, Western Cape, PO Box 351, \\ Oudtshoorn 6620, South Africa
}

\begin{abstract}
A study was conducted to determine the influence of dietary energy level on the production of breeding ostriches. Six diets varying in ME content (7.5, 8.0, 8.5, 9.0, 9.5 and 10.0 MJ ME/kg feed) were provided to both males and females at an average rate of $3.4 \mathrm{~kg} / \mathrm{bird} /$ day. Dietary protein and lysine levels were held constant respectively at 120 (g/kg feed) and $5.8(\mathrm{~g} / \mathrm{kg}$ feed). The trial ran over one breeding season and production records recorded included egg production, chick production, number of infertile eggs, number of dead-in-shell eggs and weight change of breeders. No significant differences were observed for total eggs produced per female per season (44.3 \pm 7.6 ), number of chicks hatched (15.6 \pm 4.1$)$, number of infertile eggs (11.8 \pm 3.9$)$ and for number of dead-in-shell eggs (11.9 \pm 3.1$)$. Analysis of variance revealed no significant difference in the weight change of female birds on different treatments, although regression analysis revealed an increase of $2.4 \mathrm{~kg}$ per female bird per $0.5 \mathrm{MJ}$ increase in dietary energy value of the feed. Significant differences in the weight change of male breeders were observed which ranged between 6.3 $\pm 2.7 \mathrm{~kg}$ and $18.4 \pm 2.8 \mathrm{~kg}$ over the breeding season. Overall, the weight of male breeders increased by 1.9 $\mathrm{kg}$ per $0.5 \mathrm{MJ}$ increase in dietary energy content $\left(\mathrm{R}^{2}=0.09\right)$. It was concluded that the energy supplied for both male and female breeders was in excess of their requirements, since both sexes increased in weight over the season.
\end{abstract}

Keywords: Egg production, chick production, weight change of breeders

\#Corresponding author. E-mail: tersb@elsenburg.com

\section{Introduction}

Reliable nutritional data for ostriches are scarce. Lack of nutritional data might contribute to a large variation in production of birds (Brand \& Gous, 2006) as well as poor egg production records in breeding ostriches (Brand et al., 2003).

Swart et al. (1993) calculated the energy requirement for maintenance of ostriches as $0.44 \mathrm{MJ} /($ live body weight) $\mathrm{kg}^{0.75} /$ day and efficiency of ME utilization for growth as 0.32 . Cilliers et al. (1998) on the other hand calculated that $0.425 \mathrm{MJ} /$ (empty body weight) $\mathrm{kg}^{0.75} /$ day is needed to fulfil the energy requirement for maintenance of ostriches, while the efficiency of TMEn utilization calculated as 0.443. ME utilization in ostriches according to this publication is quite low in comparison with figures published for fowls and pigs. McDonald et al. (2002) for example reported values of 0.9 and 0.85 respectively for the utilization of ME by fowls and pigs when fed a balanced diet.

Brand et al. (2003) performed a study, stretching over two breeding seasons, to determine the effect of energy and protein provision on the production of female breeding ostriches. The females laid fewer eggs at longer intervals at the lowest dietary energy level (7.5 MJ ME per kg feed at an intake of $2.5 \mathrm{~kg}$ feed per bird per day), compared to dietary energy levels of 8.5 and $9.5 \mathrm{MJ} \mathrm{ME} / \mathrm{kg}$ feed. Females also tended to lose more weight on diets containing less energy. It was concluded in this study that energy was the main constraint on egg production at crude protein and lysine levels exceeding $13.5 \%$ and $0.65 \%$, respectively, and a dietary energy level of $8.5 \mathrm{MJ} \mathrm{ME} / \mathrm{kg}$ was sufficient for female breeding birds in these studies. Nutrition related carry-over effects, from a season to the following season were also reported by Brand et al. (2002). Diets containing less than $8.5 \mathrm{MJ} \mathrm{ME} / \mathrm{kg}$ may have an adverse effect on egg production in the following breeding season. 
This study was conducted to determine the response of ostrich breeders fed rations containing different dietary energy levels at higher feed intakes and at constant dietary protein and lysine levels.

\section{Material and Methods}

Ninety pairs of breeding ostriches were divided into six groups, consisting of 15 breeding pairs per group. Six diets varying in ME content (7.5, 8.0, 8.5, 9.0, 9.5 and 10.0 MJ ME/kg feed) were provided at a rate of $3.4 \mathrm{~kg} / \mathrm{bird} /$ day to both males and females. Thus every group received 1 of the 6 diets for the duration of the trial. The age of the birds varied between two to 12 years. The study was done in Oudtshoorn (South Africa) during the 2007/2008 breeding season. The annual breeding season in South Africa starts in June and ends in January the following year. Table 1 lists the nutrient composition of each diet and Table 2 the ingredient composition of each diet. Breeding pairs were kept on a $1: 1$ sex ratio in a single breeding camp. Eggs were collected daily and the relevant rations were placed in the feeding troughs each morning.

Production parameters were measured at the end of each month. Data recorded included egg and chick production, dead-in-shell and infertile egg production. The live mass of the birds was measured at the onset and end of the season to calculate the change in mass over the season. A one-way analysis of variance (ANOVA) was performed on the data, using Statgraphics (2005). To analyze the effect of age on the data, an ANACOVA was done using Statistica (2008). Diet was used as the categorical predictor and age as the covariate.

Table 1 Nutrient composition of the six experimental diets on an as-fed basis

\begin{tabular}{|c|c|c|c|c|c|c|}
\hline \multirow{2}{*}{ Nutrient composition } & \multicolumn{6}{|c|}{ Diet } \\
\hline & 1 & 2 & 3 & 4 & 5 & 6 \\
\hline ME (MJ ME/kg feed) & 7.5 & 8.0 & 8.5 & 9.0 & 9.5 & 10.0 \\
\hline Crude protein (g/kg feed) & 120 & 120 & 120 & 120 & 120 & 120 \\
\hline Lysine (g/kg feed) & 5.8 & 5.8 & 5.8 & 5.8 & 5.8 & 5.8 \\
\hline $\begin{array}{l}\text { Methionine\&cystine (g/kg } \\
\text { feed) }\end{array}$ & 4.0 & 4.0 & 4.0 & 4.0 & 4.0 & 4.0 \\
\hline Threonine (g/kg feed) & 5.0 & 5.0 & 5.0 & 5.0 & 5.0 & 5.0 \\
\hline Arginine (g/kg feed) & 6.0 & 6.0 & 6.0 & 6.0 & 7.0 & 7.0 \\
\hline Tryptophan (g/kg feed) & 1.3 & 1.5 & 1.6 & 1.7 & 1.9 & 2.0 \\
\hline Fat (g/kg feed) & 11 & 19 & 27 & 35 & 42 & 50 \\
\hline $\begin{array}{l}\text { Fatty acid C18:2 (g/kg } \\
\text { feed) }\end{array}$ & 1.0 & 3.0 & 6.0 & 9.0 & 11 & 14 \\
\hline $\begin{array}{l}\text { Fatty acid C18:3 (g/kg } \\
\text { feed) }\end{array}$ & 1.0 & 2.0 & 4.0 & 6.0 & 8.0 & 10 \\
\hline Crude fibre (g/kg feed) & 207 & 184 & 161 & 138 & 114 & 91 \\
\hline Calcium (g/kg feed) & 28 & 27 & 26 & 26 & 25 & 24 \\
\hline Phosphorus (g/kg feed) & 6.0 & 6.0 & 6.0 & 6.0 & 5.0 & 5.0 \\
\hline
\end{tabular}

\section{Results and Discussion}

Results are displayed in Table 3 . No significant differences $(\mathrm{P}>0.05)$ were observed between treatments for total eggs produced per female per season (44.3 \pm 7.6 ), number of chicks hatched (15.6 \pm 4.1 ), number of infertile eggs $(11.8 \pm 3.9)$ and for number of dead-in-shell eggs $(11.9 \pm 3.1)$. The age of the female bird contributed to the data significantly affecting $(\mathrm{P}<0.05)$ total egg and chick production and tended $(\mathrm{P}=0.05)$ to affect the change in mass of females. ANACOVA, when age was held as the covariate, stated that older birds tended to lay more eggs, together with an increase in chick production. Old female 
birds tended to gain more body mass on dietary energy treatments, more nutrients are possibly stored as body reserves as the bird ages. Kritzinger et al. (2009) reported that the maximum weight at maturity under assumed optimal conditions of an ostrich $(119.4 \mathrm{~kg})$ will be achieved at 943 days or 2.5 years of age and can be assumed that any excess feed after mature weight will be turned into body fat (Pond et al., 2005). Data for the change in mass of females may have been skewed due to the two year old females.

Table 2 Ingredient composition of the experimental diets (kg/ton feed)

\begin{tabular}{lcccccc}
\hline \multirow{2}{*}{ Composition } & \multicolumn{7}{c}{ Diet } \\
\cline { 2 - 6 } & 1 & 2 & 3 & 4 & 5 & 6 \\
\hline Energy level (MJ ME per & 7.5 & 8.0 & 8.5 & 9.0 & 9.5 & 10.0 \\
kg feed) & 670 & 536 & 402 & 268 & 134 & 0 \\
Oat bran & 0 & 110 & 220 & 330 & 440 & 550 \\
Maize meal & 48.6 & 90.1 & 131.6 & 173 & 214.5 & 256 \\
Lucerne hay & 165 & 142.4 & 119.8 & 97.2 & 74.6 & 52 \\
Soyabean oilcake meal & 0 & 10 & 20 & 30 & 40 & 50 \\
Flaxseed & 50 & 48.8 & 47.6 & 46.4 & 45.2 & 44 \\
Limestone & 30 & 26.9 & 23.9 & 20.8 & 17.8 & 14.7 \\
Dicalcium phosphate & 20 & 20 & 20 & 20 & 20 & 20 \\
Molasses & 10 & 10 & 10 & 10 & 10 & 10 \\
Salt & 2.5 & 2.5 & 2.5 & 2.5 & 2.5 & 2.5 \\
Mineral \& vitamin premix & 0.8 & 0.8 & 0.7 & 0.7 & 0.6 & 0.6 \\
Synthetic lysine & 1.9 & 1.6 & 1.2 & 0.9 & 0.5 & 0.2 \\
Synthetic methionine & 1.2 & 1 & 0.7 & 0.5 & 0.2 & 0 \\
Synthetic threonine & & & & & & \\
\hline
\end{tabular}

Table 3 Means and standard errors for production data collected at different dietary energy levels

\begin{tabular}{|c|c|c|c|c|c|c|}
\hline Energy level (MJ ME/kg) & 7.5 & 8.0 & 8.5 & 9.0 & 9.5 & 10.0 \\
\hline Crude protein $(\mathrm{g} / \mathrm{kg})$ & 120 & 120 & 120 & 120 & 120 & 120 \\
\hline Lysine levels (\%) & 5.8 & 5.8 & 5.8 & 5.8 & 5.8 & 5.8 \\
\hline Egg production (eggs/female/season) & $40.7 \pm 7.6$ & $35.3 \pm 7.6$ & $50.4 \pm 7.4$ & $42.6 \pm 7.6$ & $49.9 \pm 7.6$ & $47.1 \pm 7.6$ \\
\hline $\begin{array}{l}\text { Chick production } \\
\text { (chicks/female/season) }\end{array}$ & $17.5 \pm 4.1$ & $11.4 \pm 4.1$ & $12.3 \pm 4.0$ & $16.5 \pm 4.1$ & $20.8 \pm 4.1$ & $15.1 \pm 4.1$ \\
\hline $\begin{array}{l}\text { Dead-in-shell eggs } \\
\text { (eggs/female/season) }\end{array}$ & $9.1 \pm 3.1$ & $11.7 \pm 3.1$ & $12.9 \pm 3.0$ & $11.5 \pm 3.1$ & $14.1 \pm 3.1$ & $11.9 \pm 3.1$ \\
\hline Infertile eggs (eggs/female/season) & $9.1 \pm 3.9$ & $8.3 \pm 3.9$ & $19.4 \pm 3.8$ & $10.7 \pm 3.9$ & $9.4 \pm 3.9$ & $13.9 \pm 3.9$ \\
\hline Change in mass of females (kg) & $4.9 \pm 3.5$ & $7.2 \pm 3.5$ & $9.3 \pm 3.6$ & $11.5 \pm 3.5$ & $14.8 \pm 3.5$ & $16.4 \pm 3.5$ \\
\hline Change in mass of males (kg) & $7.1^{\mathrm{ab}} \pm 2.7$ & $11.6^{\mathrm{ab}} \pm 2.7$ & $6.3^{\mathrm{a}} \pm 2.7$ & $14.6^{\mathrm{ab}} \pm 2.8$ & $12.0^{\mathrm{ab}} \pm 2.8$ & $18.4^{\mathrm{b}} \pm 2.8$ \\
\hline
\end{tabular}

${ }^{\text {a,b: }}$ rows with different superscripts differ significantly $(\mathrm{P}<0.05)$.

ANOVA analysis revealed no significant difference in the mass change of female birds on different treatments $(\mathrm{P}=0.17)$, although regression analysis revealed an increase of $2.4 \mathrm{~kg}$ per bird per $0.5 \mathrm{MJ}$ increase in dietary energy value $\left(\mathrm{y}=2.4 \mathrm{x}+2.45\right.$; SEest $\left.=13.19 \mathrm{~kg} ; \mathrm{R}^{2}=0.09 ; \mathrm{P}<0.05\right)$. Due to the fact that the females gained mass in each treatment, it may be assumed that the energy provided exceeded the requirements of the birds. It is assumed in this study that any excess dietary energy is turned into body fat, which leads to an increase in body weight. Lin et al. (1980) stated in studies with broilers that when energy intake is more than the body's requirement for energy, the excess food is stored as fat. Pond et al. (2005) 
explained that energy intake which is more than the current needs results in a net deposition of triglycerides and the animal will consequently become fatter.

Significant differences $(\mathrm{P}<0.05)$ in the mass change of male breeders were observed which ranged between $6.3 \pm 2.7 \mathrm{~kg}$ and $18.4 \pm 2.8 \mathrm{~kg}$ over the breeding season. The significant difference was between the 8.5 and $10.0 \mathrm{MJ} \mathrm{ME} / \mathrm{kg}$ diet. The linear regression line of live mass over time for the males indicated a growth of $1.9 \mathrm{~kg}$ per $0.5 \mathrm{MJ}$ increase in dietary energy value for the trial period $(\mathrm{y}=1.9 \mathrm{x}+5$; SEest $=10.5$ $\mathrm{kg} ; \mathrm{R}^{2}=0.09 ; \mathrm{P}<0.05$ ). The differences between the males can be ascribed to higher fat accretion in the body of those males that were fed a diet higher in ME content. Due to mass gain, the energy provided also exceeded their requirements.

\section{Conclusion}

This study indicates that dietary energy has no influence on production data of breeding ostriches if the daily energy allotment exceeds 25.5 MJ ME per bird per day. Previous studies revealed that a daily ration below 22 MJ ME per bird per day will probably result in lower egg production (Brand et al., 2003). Rations formulated to provide an energy intake of 22 MJ ME per bird per day seem therefore to be the most economical option for feeding breeding ostriches at the stated production levels (Brand, 2008).

\section{References}

Brand, T.S., 2008. Volstruisvoeding: 'n Wetenskaplike benadering. Sun Print, University of Stellenbosch, Stellenbosch. pp. 48.

Brand, T.S. \& Gous, R.M., 2006. Feeding Ostriches. In: Feeding in Domestic Vertebrates: From Structure to Behaviour. Ed. Bels, V., CAB International, Wallingford, England. pp. 136-155.

Brand, Z., Brand, T.S. \& Brown, C.R., 2002. The effect of dietary and protein levels during a breeding season of ostriches (Struthio camelus domesticus) on production the following season. S. Afr. J. Anim. Sci. 32, 226-230.

Brand, Z., Brand, T.S. \& Brown, C.R., 2003. The effect of dietary energy and protein levels on production in breeding female ostriches. Br. Poult. Sci. 44, 598-606.

Cilliers, S.C., Hayes, J.P., Chwalibog, A., Du Preez, J.J. \& Sales, J., 1998. Determination of energy, protein and amino acid requirements for maintenance and growth in ostriches. Anim. Feed Sci. Technol. 72, 283-292.

Kritzinger, W.J., Brand, T.S., Hoffman, L.C. \& Mellett, F.D., 2009. A description of body composition change in ostriches (Struthio camelus) under optimal feeding conditions. South Africa Society of Animal Science's $43^{\text {rd }}$ Congress, 28-30 July 2009, Bergville, South Africa

Lin, C.Y., Friars, G.W. \& Moran, E.T., 1980. Genetic and environmental aspects of obesity in broilers. Wrld's Poult. Sci. J. 36, 103-111.

McDonald, P., Edwards, R.A., Greenhalgh, J.F.D. \& Morgan, C.A., 2002. Animal Nutrition. $6^{\text {th }}$ ed. Prentice Hall, Harlow, England. pp. 286.

Pond, W.G., Church, D.C., Pond, K.R. \& Schoknecht, P.A., 2005. Basic Animal Nutrition and Feeding. $5^{\text {th }}$ ed. John Wiley \& Sons, Inc. pp.100.

Swart, D., Siebrits, F.K. \& Hayes, J.P., 1993. Utilization of metabolizable energy by ostrich (Struthio camelus) chicks at two different concentrations of dietary energy and crude fibre originating from lucerne. S. Afr. J. Anim. Sci. 23, 136-141. 